University of Windsor

Scholarship at UWindsor

2018

\title{
Mark report satellite tags (mrPATs) to detail large-scale horizontal movements of deep water species: First results for the Greenland shark (Somniosus microcephalus)
}

\author{
Nigel E. Hussey \\ Biological Sciences, University of Windsor \\ Jack Orr \\ Aaron T. Fisk \\ University of Windsor \\ Kevin J. Hedges \\ Steven H. Ferguson
}

See next page for additional authors

Follow this and additional works at: https://scholar.uwindsor.ca/biologypub

Part of the Biology Commons

\section{Recommended Citation}

Hussey, Nigel E.; Orr, Jack; Fisk, Aaron T.; Hedges, Kevin J.; Ferguson, Steven H.; and Barkley, Amanda N., "Mark report satellite tags (mrPATs) to detail large-scale horizontal movements of deep water species: First results for the Greenland shark (Somniosus microcephalus)" (2018). Deep Sea Research Part l: Oceanographic Research Papers.

https://scholar.uwindsor.ca/biologypub/1193

This Article is brought to you for free and open access by the Department of Biological Sciences at Scholarship at UWindsor. It has been accepted for inclusion in Biological Sciences Publications by an authorized administrator of Scholarship at UWindsor. For more information, please contact scholarship@uwindsor.ca. 
Authors

Nigel E. Hussey, Jack Orr, Aaron T. Fisk, Kevin J. Hedges, Steven H. Ferguson, and Amanda N. Barkley 


\section{Author's Accepted Manuscript}

Mark report satellite tags (mrPATs) to detail largescale horizontal movements of deep water species: First results for the Greenland shark (Somniosus microcephalus)

Nigel E. Hussey, Jack Orr, Aaron T. Fisk, Kevin J. Hedges, Steven H. Ferguson, Amanda N. Barkley

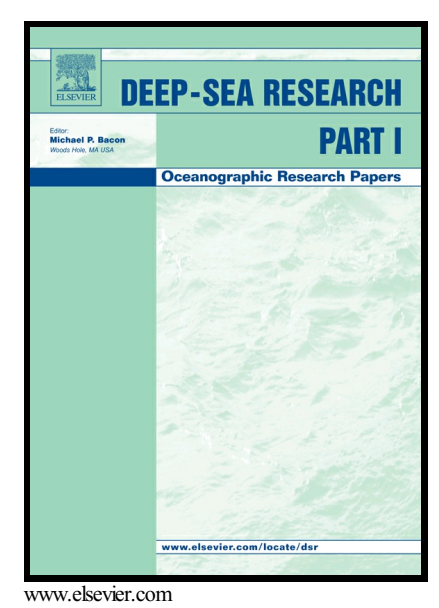

PII: $\quad$ S0967-0637(17)30384-9

DOI: $\quad$ https://doi.org/10.1016/j.dsr.2018.03.002

Reference: DSRI2884

To appear in: Deep-Sea Research Part I

Received date: 13 December 2017

Revised date: 3 March 2018

Accepted date: 4 March 2018

Cite this article as: Nigel E. Hussey, Jack Orr, Aaron T. Fisk, Kevin J. Hedges, Steven H. Ferguson and Amanda N. Barkley, Mark report satellite tags (mrPATs) to detail large-scale horizontal movements of deep water species: First results for the Greenland shark (Somniosus microcephalus), Deep-Sea Research Part I, https://doi.org/10.1016/j.dsr.2018.03.002

This is a PDF file of an unedited manuscript that has been accepted for publication. As a service to our customers we are providing this early version of the manuscript. The manuscript will undergo copyediting, typesetting, and review of the resulting galley proof before it is published in its final citable form. Please note that during the production process errors may be discovered which could affect the content, and all legal disclaimers that apply to the journal pertain. 
Mark report satellite tags (mrPATs) to detail large-scale horizontal movements of deep water species: First results for the Greenland shark (Somniosus microcephalus)

Nigel E. Hussey ${ }^{1}$, Jack Orr $^{2}$, Aaron T. Fisk ${ }^{3}$, Kevin J. Hedges ${ }^{2}$, Steven H. Ferguson ${ }^{2,4}$, and Amanda N. Barkley ${ }^{1}$

${ }^{1}$ Biological Sciences, University of Windsor, 401 Sunset Avenue, Windsor, Ontario. N9B 3P4. Canada

${ }^{2}$ Fisheries and Oceans Canada, Winnipeg, Manitoba. R3T 2N6. Canada

${ }^{3}$ Great Lakes Institute for Environmental Research, University of Windsor, 401 Sunset Avenue, Windsor, Ontario. N9B 3P4. Canada

${ }^{4}$ Department of Biological Sciences, University of Manitoba, 501 University Crescent, Winnipeg, Manitoba. R3T 2N2. Canada

Running header: Novel horizontal tracking of deep water species 


\section{Abstract}

The deep-sea is increasingly viewed as a lucrative environment for the growth of resource extraction industries. To date, our ability to study deep-sea species lags behind that of those inhabiting the photic zone limiting scientific data available for management. In particular, knowledge of horizontal movements is restricted to two locations; capture and recapture, with no temporal information on absolute animal locations between endpoints. To elucidate the horizontal movements of a large deep-sea fish, a novel tagging approach was adopted using the smallest available prototype satellite tag - the mark-report satellite tag (mrPAT). Five Greenland sharks (Somniosus microcephalus) were equipped with multiple mrPATs as well as an archival satellite tag (miniPAT) that were programmed to release in sequence at 8-10 day intervals. The performance of the mrPATs was quantified. The tagging approach provided multiple locations per individual and revealed a previously unknown directed migration of Greenland sharks from the Canadian high Arctic to Northwest Greenland. All tags reported locations, however the accuracy and time from expected release were variable among tags (average time to an accurate location from expected release $=30.8 \mathrm{~h}$, range: $4.9-227.6 \mathrm{~h}$ ). Average mrPAT drift rate estimated from best quality messages (LQ1,2,3) was $0.37 \pm 0.09 \mathrm{~m} / \mathrm{s}$ indicating tags were on average $41.1 \pm 63.4 \mathrm{~km}$ (range: $6.5-303.1 \mathrm{~km}$ from the location of the animal when they transmitted. mrPATs provided daily temperature values that were highly correlated among tags and with the miniPAT (70.8\% of tag pairs were significant). In contrast, daily tilt sensor data were variable among tags on the same animal $(12.5 \%$ of tag pairs were significant). Tracking large-scale movements of deep-sea fish has historically been limited by the remote environment they inhabit. The current study provides a new approach to document reliable coarse scale horizontal movements to understand migrations, stock structure and habitat use of large species. Opportunities to apply mrPATs to understand the movements of medium size fish, marine mammals and to validate retrospective movement modelling approaches based on archival data are presented. 
Keywords: benthic, deep-sea, Greenland shark, migration, miniPAT, mrPAT, satellite telemetry

\section{Introduction}

Our understanding of the structure of deep-sea ecosystems and the ecological roles of individual species remain poorly understood as a result of logistical challenges. The deep sea, defined as waters and bottom habitat $>200 \mathrm{~m}$, forms the largest environment on Earth with open waters constituting $98.5 \%$ by volume and bottom habitat equating to $63 \%$ of total area (Thurber et al., 2014). Traditionally considered a dark, barren and hostile environment that is low in diversity and biomass, it is now recognized that deep sea ecosystems support diverse habitats and species assemblages and provide critical ecosystem functions and services (Grassle \& Maciolek 1992; Danovaro et al., 2008). Importantly, nutrient regeneration and global biogeochemical cycles are critical to ensure ocean functioning through Earth's homeostasis, including mitigating global climate change driven by anthropogenic emissions (Bigg, Jickells, \& Liss 2003). Most species residing in the deep sea are adapted to its extreme depth and temperature regimes through delayed maturity, greater longevity and low average productivity (k-selected traits; Koslow, 1996). This results in low fish stock productivity and therefore the need for a precautionary approach when extracting resources from this environment (Koslow et al., 2000).

Despite these sensitive traits, the deep sea is viewed as one of the most lucrative environments for resource extraction, from fishing, hydrocarbon extraction and mining, activities which are all expanding with an ever-increasing footprint (Schiermeier, 2012; AFWG-ICES 2013; Morato, Cheung, \& Pitcher 2006). Although resource extraction is feasible, its impact on deep water ecosystems has raised concern, based on limited knowledge of species biology and ecology. Evidence for fisheries collapses (Koslow et al. 2000) and long-term impacts of human activities on the seabed support these concerns (Kaiser, Collie, Hall, Jennings, \& Poiner 2002). This issue is further exacerbated in remote and hostile environments such as the Arctic where even fewer data exist, but 
decreasing ice extent is improving access, while human development and exploitation of natural resources are growing (Christiansen, Mecklenburg, \& Karamushko 2013).

For improved understanding of deep-sea ecosystems, data on animal movements in space and time and the scales over which those movements occur is required (Cotton \& Grubbs, 2015). Animal movements dictate species interactions which in turn structure food webs through energy transfer among trophic levels and the coupling of distant ecosystem components, as well as facilitating dispersal to maintain viable populations. In the photic zone, modern telemetry is providing ground-breaking insights in to both the horizontal and vertical movements of a diverse range of species (Hussey et al., 2015a) but for most deep-water species that reside below the photic zone, light level data required for geolocation is not recorded. This results in satellite approaches providing detailed dive behavior for deep water species, while horizontal data is limited to revealing only the capture and pop off location with no indication of absolute locations between those two time points (Peklova, Hussey, Hedges, Treble, \& Fisk 2012, 2014; Comfort \& Weng, 2015; Rodriguez-Cabello \& Sanchez, 2014). Initial modeling approaches have incorporated various parameters including bottom topography, swim speeds, tidal cycles and vertical temperature profiles in conjunction with archival tag data to retrospectively estimate horizontal locations (Hunter, Aldrifge, Metcalfe, \& Arnold 2003; Hunter, Metcalfe, Holford, \& Arnold 2004; Skomal et al., 2009; Chittenden, Adlandsvik, Pedersen, Righton, \& Rikardsen 2013). These methods show promise for reconstructing horizontal locations for deep water species, but currently location data are poor quality with large error estimates and there is limited scope for validation. While acoustic telemetry data, based on fixed receivers detecting tagged fish is emerging and providing horizontal movement data for deep water fish (Afonso, Graca, Berke, \& Fontes 2012; Daly, Williams, Green, Barker, \& Brodie 2015; Weng, 2013; Hussey et al., 2017), these studies are commonly restricted in terms of their scale of monitoring. New satellite telemetry approaches are required to address this data gap.

In this study, we tested the prototype of the smallest pop up satellite tag developed to date, the mark-report satellite tag (mrPAT; Wildife computers Ltd, Redmond, Seattle). This satellite tag is designed to provide a location estimate for an animal at a preprogrammed pop off date and ancillary temperature and tilt data. Our objective was to 
test a novel tagging approach whereby multiple mrPATs were attached to a large mobile deep water species, to determine the potential for these tags to generate coarse scale data on large-scale horizontal movements $(>10 \mathrm{~km})$ of individuals that to date have not been possible. Specifically, we examined the performance of mrPATs for providing acceptable location data and ancillary environmental data. We highlight potential applications for mrPATs that will assist our understanding of the ecology of both shallow and deep water species and provide data to inform fisheries and conservation management planning.

\section{Methods}

Study site

The study was conducted in Steiness Fjord, near the Inuit community of Grise Fjord, Jones Sound, Eastern Canadian Arctic and was focused on the Greenland shark (Somniousus microcephalus), a large long-lived species that typically occurs in deep waters and for which few horizontal movement data exist (MacNeil et al. 2012; Nielsen et al. 2016).

\section{Fishing and animal handling}

Greenland sharks were caught using short bottom longlines (S1). Following soak times of 12-24 h, captured sharks were inverted and secured next to a small boat to record standard morphometric data (length/sex/clasper size; see S2). Following data recording, the animal was reoriented dorsal side upwards to attach mark report (mrPAT) and archival pop up satellite tags (miniPATs; Wildlife Computers Ltd, Redmond, Seattle, USA).

Greenland shark muscle tissue is extremely soft which restricts the retention of standard darts to secure satellite tags (see early shed rate for miniPATs, Fisk et al. 2012 and Campana et al. 2015). In addition, the study aimed to attach multiple satellite tags per individual shark which would require several dart insertions. Consequently, a new fin attachment plate was designed to improve tag retention, based on real time transmitting satellite tags affixed to the dorsal fins of sharks (SPOTs; Lea et al., 2015). The attachment plates were triangular shaped, constructed of a strong plastic polymer and attached to the dorsal fin using plastic bolts and stainless steel lock nuts (Fig. 1). Two 
plates were placed, one either side of the dorsal fin and attached using a single set of bolts, to limit tag collisions and damage while attached to the animal (Fig. 1).

Individual satellite tags were attached to raised contact points on the triangular plate via crimps and $\sim 10 \mathrm{~cm}$ length of leader wire. For three sharks, three mrPATs were attached on one plate and one mrPAT and a miniPAT on the second plate (Fig. 1). For two individuals, only two mrPATs were attached to one plate with an identical set up as the other animals on the second plate. Following all tagging and sampling procedures ( $<20$ mins), restraining ropes were removed and the animal released. All sharks were categorized as either juvenile, sub-adult or adult based on size and reproductive development according to Yano, Stevens and Compagno (2007) and Hussey et al. (2015b).

\section{Satellite tags}

The mrPAT is the smallest design pop up satellite tags constructed to date (121 mm long, $23 \mathrm{~mm}$ diameter and weight of $26 \mathrm{~g}$ ) and was designed to provide a cost-effective way of deriving fisheries independent locations in large-scale movement studies. To minimize the size of the prototype tag (see new tag design at www.wildlifecomputers.com), the antenna is coiled within a housed nose cap at the release point (orange cap in Fig. 1), and uncoils following the release of the tag from the animal. The release mechanism is a standard burn pin, identical to standard pop up archival tags (miniPATs) and data is transmitted to ARGOS via a $0.5 \mathrm{~W}$ Argos Transmitter. During deployment, each tag is factory programmed to collect temperature and tilt data (i.e. tag orientation). Over the period of each UTC day (midnight to midnight) the tag records temperature and tilt data every 10 minutes. For temperature, these data are summarized as the min and max value per day (resolution of $+/-0.5^{\circ} \mathrm{C}$; range $-20-50^{\circ} \mathrm{C}$ ), for tag orientation, one tilt value is provided per day $\left(+/-2^{0:} 0\right.$ [orange cone orientated upwards] $-180^{\circ}$ [orange cone orientated downwards]) calculated as the average of the daily minimum and maximum tilt and transmitted to the nearest degree. On the pre-programmed release date, the tag detaches from the animal at midnight, and once at the surface (identified by a standard wet/dry sensor), transmits data to overhead ARGOS satellites via the uncoiled antenna. 
The tags use a continuous Argos uplink to transmit locations with a battery life estimated to allow data transmission for up to 10 days.

The mrPATs were programmed to detach from individual sharks and provide a location every 8-10 days depending on when the shark was tagged (earlier or later during fieldwork) and how many mrPATs were attached (three versus four; Table 1; S3).

The miniPATs were programmed to collect depth/temperature time series data every $75 \mathrm{~s}$ over the entire deployment period of the mrPATs in addition to 12-hour binned summary data. All pop up archival satellite tags were programmed as the last tag to release from each shark between 8-10 days following the release of the final mrPAT. Tags were programmed to transmit by the end of September $\left(25^{\text {th }}\right.$ and $30^{\text {th }}$ September $)$ prior to the formation of sea ice in the high Arctic.

\section{Data analyses}

All mrPAT and miniPAT data were compiled for each shark, cleaned and summarized. (S4). To examine the performance of each mrPAT for transmitting location data, we first calculated the difference in time $(\mathrm{h})$ between the first transmission received relative to the actual programmed pop off date. Then we calculated the time from the first mrPAT transmission to each of the acceptable location accuracy estimates $(3,2$ and 1$)$ to show the time frame from mrPAT pop off to derive reasonable location data. In addition, given the potential of the mrPAT to drift from the actual pop off location during transmissions, and the fact that it may take time to obtain an acceptable location estimate (i.e. only A and B estimates may be received at first), we also estimated the drift rate for each mrPAT over the total transmission period. Drift rate (meters/second) was calculated by dividing all LQs 3, 2, and 1 transmissions over the entire study period, by the total transmission time of these locations. For miniPATs, the same calculations as above were undertaken allowing a comparison of time to acceptable location estimates between the two tag types.

To determine the reliability of ancillary mrPAT measurements (daily temperature and tilt angle), data for each mrPAT for each day (min and max value) were plotted over the entire deployment period of all mrPATs per shark. In addition, daily min max temperatures were extracted from each miniPAT and these data compared with those of 
the mrPATs for the same deployment period. Statistical comparison of the temperature range recorded for each mrPAT and miniPAT (max temp - min temp), was performed using correlation analysis with the pairwise complete method to handle missing values (as tags pop-off the shark), and a Pearson correlation coefficient in $\mathrm{R}$ ( $\mathrm{R}$ statistical computing software). The same correlation analysis was used on the tilt data, but note miniPATs do not record tilt information and therefore were excluded.

Finally, the first acceptable location estimates (3,2 or 1) for each mrPAT tag and miniPAT per individual shark were extracted and mapped to provide the first large-scale horizontal movement patterns of Greenland sharks. For each mrPAT and miniPAT, a location estimate of 3 was used if it transmitted within $2 \mathrm{~h}$ of the first tag transmission, after which the first acceptable location estimate was used. This $2 \mathrm{hr}$ window was based on an average calculated tag drift rate of $0.37 \mathrm{~m} / \mathrm{s}$, i.e. the animal would be within $2.7 \mathrm{~km}$ of the original pop-up site.

\section{Results}

Five Greenland sharks were equipped with mrPATs and a miniPAT in Steiness Fjord ranging in size from 175 to $310 \mathrm{~cm}$ TL and included both sexes (Table 2; 76.892 $\mathrm{N}$, $\left.82.156^{\circ} \mathrm{W}\right)$. Of the $18 \mathrm{mrPATs}$ attached to sharks, all tags (100\%) reported location and ancillary temperature/tilt data to satellites. In addition, all five miniPATs successfully transmitted the final location for each animal and summary time series depth/temperature data. Total tracking time ranged from 34 to 45 days (38 \pm 4 mean plus/minus SD), with mrPATs reporting locations on average every 8 days (range 4-10 days; Table 1 and 2).

The majority of mrPATs popped off and connected with satellites on the preprogrammed release date $(n=15,83 \%$; Table 1$)$. Of the 3 tags that reported data later, two transmitted messages on the expected release date, but did not give a location until 1 to 4 days later. The third failed to connect to the satellite for 6 days after the expected release date, and did not transmit a location until 8 days later (Table 1; Fig. 2). The actual number of days that the mrPATs transmitted data and the number of location estimates received was highly variable among tags. The number of transmission days was on average 7.1 , ranging from 0.2 to 11.9 , while the average number of LQ 1,2 or 3 
messages was 237, ranging from 0 to 538 (average of all quality locations was 486; range: $10-887)$.

When considering the time to receive accurate ARGOS location estimates, on average mrPATs provided 3, 2 and 1 LQ messages within 13.6, 14.5 and 11.2 hours respectively, of the first message transmitted to satellites (range $0.04-110.76$ hours), while the time from expected release to the chosen location (i.e. first transmission of LQ 1,2 , or 3 message) for each shark was higher $(30.8 \pm 48.7 \mathrm{~h}$, range $=4.9-227.6 \mathrm{~h})$. Average drift rate for all tags estimated using 1, 2 and 3 LQ messages, was $0.37 \pm 0.09$ $\mathrm{m} / \mathrm{s}$ identifying tags were on average $41.1 \pm 63.4 \mathrm{~km}$ (range: $6.5-303.1 \mathrm{~km}$, based on the difference between expected and actual report time, multiplied by drift) from the actual location of the animal when they transmitted. The drift direction of the tags was dependent on pop-up location, but predominantly followed known surface current patterns for the area (Fig. 3; Melling, Gratton, \& Ingram 2000). Only one tag did not provide a 1, 2, or 3 location quality message (mrPAT tag 1 on Shark 2; Fig. 3).

In terms of ancillary mrPAT data, there was a reasonable correlation between minimum and maximum temperature recorded among mrPATs attached per individual shark (deployed over different time intervals), with correlation analysis significant for $70.8 \%$ of mrPAT tag pairs (Fig. 4; S5 and Fig. S1). When compared to miniPAT summary values, mrPATs on each shark systematically recorded a slightly lower temperature range, but correlation analysis still indicated strong significance for $72.2 \%$ of the mrPAT and miniPAT pairs (Fig. 4; S5 and Fig. S1).

For the tilt sensor, the average tilt values across all mrPATs was $91 \pm 11$ (range 54 to 125). Tilt values were rarely correlated among tags attached to the same shark with only $12.5 \%$ of all pairs being significant (S6 and Fig. S2).

From the tagging location in Steiness Fjord, all the Greenland sharks undertook a directed movement passing between northeast Devon Island and Coburg Island, across the open water of northern Baffin Bay and then entering the coastal waters and fjords off northwest Greenland from Inglefield Bredning to Melville Bay (Fig. 5a). A location estimate for shark 5 did not occur off northeast Devon Island but this was likely a result of the timing of the tag release and the fact that the mrPAT reported several days late (Fig. 2). Sharks transited via northeast Devon Island between the $24^{\text {th }}$ August and $1^{\text {st }}$ 
September and took approximately 16 days to cross the open waters of Baffin Bay arriving in the vicinity of coastal regions of Greenland between the $5^{\text {th }}$ and the $20^{\text {th }}$ September. The mrPATs on two sharks (Shark 1 and 2) revealed they likely remained in the region of Grise Fjord for 5 and 10 days post tagging and prior to undertaking the large-scale movement (Fig. 5a). The average total straight line distance moved by the sharks from tagging to final pop off location including all tag locations between those points was $535.4 \mathrm{~km}$ and ranged from a minimum of $414.3 \mathrm{~km}$ to a maximum of 617.1. Two sharks (individuals 3 and 4), entered the inner section of Inglefield Bredning and Mellville Bay fjords, with the latter shark entering two independent fjords (Fig 5a). Over the monitored period, sharks occurred on average for 15 days in coastal waters off Greenland; maximum and minimum of 10 and 22 days, respectively (Fig. 5a). Similarly, a mrPAT and a mrPAT and miniPAT attached to two Greenland sharks tagged in Grise Fjord in 2014 popped off in the same region over the same time period (Fig. 5b; Table 2) suggesting a potential migration route for Greenland sharks that may occur on an annual basis.

\section{Discussion}

Our understanding of the long-term horizontal movements of deep-water species has to date been limited to the point of capture and recapture locations with no data between endpoints. In certain instances, data suggest deep-water animals undertake limited movements even when at liberty for periods of years (Hansen, 1963), while other data demonstrate large-scale complex movements, but with poor resolution (Hansen, 1963; Godø \& Haug, 1988; Albert \& Vollen, 2014). More recently, active acoustic tracking is providing short term detailed horizontal tracks of mobile deep water species over hours to days (Afonso et al., 2014) and passive acoustic telemetry is beginning to reveal coarse scale movements over longer periods (Afonso, Graca, Berke, \& Fontes 2012; Daly, Williams, Green, Barker, \& Brodie 2015; Weng, 2013; Hussey et al., 2017). Our multiple mrPATs method, however, allowed the first long term tracking of a large mobile deep water species in near real time. The new satellite tag technology provided accurate and reliable location estimates for an animal typically inhabiting non-photic depths $>200 \mathrm{~m}$. Considering growing interest in the exploitation of deep water ecosystems, this 
technology opens new avenues to understand the spatial dynamics and interactions of deep water species. We explore further opportunities for how this technology could be applied to understand the movement ecology of a variety of medium to large aquatic species.

In most cases, the mrPATs provided accurate location estimates for individual Greenland sharks within acceptable timeframes of the programmed tag pop off date. This provided confidence in generating animal location data using mrPATs given the expected level of ARGOS error and the scale of the animal movements, i.e. they were actively moving and we were not expecting to track animals over a fine spatial scale (i.e. 10s to 100s of meters). The ability to retrospectively estimate tag drift speed and direction of drift while the tag was floating at the surface allowed estimation of the likely tag pop off location even for the few tags where the initial location data occurred days after release. To date several satellite telemetry studies have examined movement behavior of deep water species, but these have been limited to basic interpretation of horizontal data, similar to traditional tag recapture studies (Peklova, Hussey, Hedges, Treble, \& Fisk 2012; Fisk, Lyderson, \& Kovacs 2012; Campana, Fisk, \& Klimley 2015). Passive acoustic telemetry has recently investigated movements of Greenland halibut over scales of $10 \mathrm{~s}$ to $100 \mathrm{~s} \mathrm{~km}$ at depths of $>1000 \mathrm{~m}$ in the Arctic (Hussey et al., 2017; Barkley, Fisk, Hedges, Treble \& Hussey 2018). With the growth of the telemetry network approach (Hussey et al., 2015a) and technological advancements (Lennox et al., 2017), acoustic telemetry will ultimately allow monitoring of mobile deep-water species at relevant scales, from localized bays to ocean basins, but the resolution of the data will still likely be limited by the number of receivers deployed. While the mrPATs only provided a location for individual sharks every few days, this location was not dependent on the animal passing by fixed receivers and allowed a continuous track of each animal without a priori knowledge of their movement patterns and in regions without receiver stations. It is important to note, however, that this study was conducted in the high Arctic where the number of ARGOS satellite passes are significantly higher than at lower latitudes and therefore study location is an important factor to consider during study design.

For air breathers such as reptiles and marine mammals and several teleost and elasmobranchs that commonly occur at the surface, ARGOS derived surface locations 
and fast loc GPS can provide high resolution location data on a frequent basis (Bailey et al., 2008). Tracking of white sharks (Carcharodon carcharias), for example, provided several accurate locations per day over periods of up to two years (Domeier \& NasbyLucas 2013). At present the size of mrPATs limits the number of individual tags that can be attached to an animal and therefore the resolution of location data and the timeframe of monitoring. As a result, this approach to generate horizontal data for deep water organisms is most suited to large elasmobranch and teleost species. With continued tag miniaturization and consideration of the tag attachment method, the application of mrPATs will become more applicable to study mid-sized species and would enable tracking of larger species over longer time periods through attachment of more tags.

While the approach of attaching multiple mrPATs to a large shark species $(>1.5 \mathrm{~m}$ TL) is not feasible for mid-sized fish species (typically $<1 \mathrm{~m}$ TL), a different methodological approach could be adopted to generate coarse, but accurate horizontal track data for both deep and shallower water species. For example, mid-size fish such as Greenland halibut (Reinhardtius hippoglossoides), could be equipped with a single mrPAT, and multiple fish tagged at the same time with release dates programmed consecutively over a period of days, weeks or months. This would provide insight into whether individuals of a species undertake systematic migrations, reside in a single location or whether population level movements are random.

Aside from fish, there is also potential to use mrPATs to assist monitoring of marine mammal movements. For example, most near real time satellite tags attached to narwhal (Monodon monoceros) and beluga (Delphinapterus leucas) in the Arctic shed early (Reeves \& Aubin 2001). While these tags provide high-resolution data on the location of the animal and its diving behavior (and environment), commonly the tags do not remain on the animal long enough (i.e. 12 months) to measure annual fidelity and assess stock structure. Due to their small size, mrPATs could be attached to narwhal and beluga using crossbow darts, tagging poles or air guns rather than via live capture. This would facilitate both tagging in different seasons (e.g., flow edge in winter versus summer) and the tagging of a larger number of individuals to better understand population level movement dynamics. The development of a single mrPAT approach on fish and mammals could take advantage of large tag-recapture and fisheries/mammal distribution 
data sets and traditional knowledge, to formulate and test hypotheses on residency and movement.

While PSATs record light level and temperature data that can then be used in conjunction with various modeling approaches to derive location estimates for animals post tracking (Musyl et al., 2001; Nielsen, Bigelow, Musyl, \& Sibert 2006), these location data are known to have error margins and uncertainty. In most instances, these location data are only suitable for tracking species that undertake large-scale migration such as Bluefin tuna (Thunnus thynnus; Block et al., 2001; Thunnus maccoyii; Patterson, Evans, Carter, \& Gunn 2008). For deep water ecosystems, where no light level data are available for geolocation, there has been increasing interest in novel models to reconstruct horizontal movements of PSAT and archival tagged species. Initial models used combinations of bottom topography, swim speeds, tidal cycles and oceanographic models or vertical temperature profiles combined with PSAT/archival temperature and depth data to reconstruct movements of basking sharks (Cetorhinus maximus; Skomal et al., 2009), plaice (Pleuronectes platessa; Hunter, Aldridge, Metcalfe, \& Arnold 2003; Hunter, Metcalfe, Holford, \& Arnold 2004) and Atlantic cod (Gadus morhua; Anderson, Nielsen, Thygesen, Hinrichsen, \& Neuenfeldt 2007; Neuenfeldt, Hinrichsen, Nielsen, \& Andersen 2007). These methods are continually improving location estimates and reducing uncertainty, but have yet to be truly validated. The mrPAT tag provides an opportunity to validate the location estimates of these models, whereby multiple or even a single tag could be attached along with a PSAT to an animal.

The resolution of the $\min / \max$ ancillary temperature data logged by the mrPATs was highly correlated with that of the archived miniPAT, indicating the reliability of these data. There were minor discrepancies, for example, mrPATs recorded a lower minimum range of temperatures than PSATs. This is likely related to the resolution of the sensor and possibly the data collection and processing/binning method both of which can be corrected. Tilt data recorded by the mrPATs also provided a measure that the animal was alive and mobile, but variation among tags attached to the same individual, suggests that other factors aside from animal orientation are affecting tilt data. The inclusion of additional sensors such as salinity, dissolved oxygen and acceleration could provide 
insights to better understand the ecology of deep water species for fisheries management and conservation planning.

Specifically, these mrPAT data for five Greenland sharks tagged in the high Arctic identified a directed migration to northwest Greenland. The location of individual sharks when consecutive mrPATs popped off indicated that shark movements occurred at a similar time, suggesting an overall synchronization of movements or a potential seasonal migration route. The reported slow swimming speed of this species $\left(0.34 \mathrm{~ms}^{-1}\right.$; Watanabe et al. 2012) coupled with the short time taken for all sharks to travel to northwest Greenland ( 16 days) would also indicate the animals were making a directed migration. Previous pop up archival tagging of Greenland sharks off Svalbard showed large-scale movements, but the direction of migration was random with animals headed in all directions when departing coastal waters (Fisk, Lyderson, \& Kovacs 2012). In Cumberland Sound, the lower Canadian Arctic, and off Nova Scotia, PSAT pop off locations suggested animals were potentially undertaking more directed migrations, similar to the movements observed here, but given the lack of data between tracking points this remains to be confirmed (Campana, Fisk, \& Klimley 2015). Sharks tagged in Cumberland Sound, however, made northern movements to the same region as those in this study, identifying this as a potential winter hotspot for the seasonal occurrence of this species in Arctic waters (Campana, Fisk, \& Klimley 2015). Previous aerial survey data reported the region off northwest Greenland to be of particular importance for large aggregations of narwhal in late summer (Heide-Jorgensen et al. 2010). The North Water Polynya (NWP; Pikialasorsuaq), the open ocean region between Jones Sound and northwest Greenland, in the central section where the sharks traversed is also a known highly productive environment during the winter months (Heide-Jorgensen et al. 2012). It is therefore plausible that Greenland sharks move to coastal fjords off Greenland to exploit abundant food resources in association with other predators and that the NWP biological hotspot may provide key habitat for Greenland sharks during the winter months. Further work is required to understand the mechanisms driving the association and co-occurrence of predatory fish such as Greenland sharks and marine mammals in the Arctic. 
In conclusion, mrPATs show promise for revealing complex movement behaviors of deep water animals in our oceans, that have until now not been possible. Identifying the first directed migration of Greenland sharks provides unique insight into the behavior of this difficult to study species and raises new opportunities to derive data for management of little-known deep-water ecosystems. In addition, there is the potential through well considered experimental design to attach single mrPATs to mid-size fish and marine mammals to observe population level movements that could generate rapid data, when compared to traditional tag recapture or live capture studies, respectively.

\section{Acknowledgements}

We thank Janelle Kennedy and the Government of Nunavut for their continued support, community members of Grise Fjord and Department of Fisheries and Oceans for field operations to undertake the work and Natalie Crandall, Melinda Holland and Matthew Rutishauser from Wildlife computers for assistance with tag methods/data processing. $\mathrm{NEH}, \mathrm{KH}$ and ATF were funded by the Government of Nunavut and NEH by the World Wildlife Fund.

\section{Authors' contribution}

$\mathrm{NEH}$ conceived the ideas and designed methodology; NEH, JO, AF and SH organized logistics and provided materials; NEH and JO, collected the data; ANB and NEH analyzed the data; NEH led the writing of the manuscript with ANB. All authors contributed critically to the drafts and gave final approval for publication.

\section{References:}

AFWG-ICES (2013). Arctic Fisheries Working Group. International Council for the Exploration of the Sea. Available at: http://www.ices.dk/community/groups/ Pages/AFWG.aspx (accessed $29^{\text {th }}$ January 2016).

Afonso, P., Graca, G., Berke, G., \& Fontes, J. (2012). First observations on seamount habitat use of blackspot seabream (Pagellus bogaraveo) using acoustic telemetry. Journal 
of Experimental Marine Biology and Ecology, 436, 1-10. doi: 10.1016/j.jembe.2012.08.003

Afonso, P., McGinty, N., Graca, G., Fontes, J., Inacio, M. Totland, A., \& Menezes, G. (2014). Vertical migrations of a deep-sea fish and its prey. PLOS one, 9(5): e97884. doi: 10.1371/ journal.pone.0097884

Albert, O.T., \& Vollen, T. (2014). A major nursery area around the Svalbard archipelago provides recruits fro the stocks in both Greenland halibut management areas in the Northeast Atlantic. ICES Journal of Marine Science, 72, 872-879. doi: 10.1093/icesjms/fsu191

Anderson, K.H., Nielsen, A., Thygesen, U.H., Hinrichsen, H.H., \& Neuenfeldt, S. (2007). Using the particle filter to geolocate Atlantic cod (Gadus morhua) in the Baltic Sea, with special emphasis on determining uncertainty. Canadian Journal of Fisheries and Aquatic Sciences, 64, 618-627. doi: 10.1139/f07-037

Bailey, H., Shillinger, G., Palacios, D., Bograd, S., Spotila, J., Paladino, F., \& Block, B. (2008). Identifying and comparing phases of movements by leatherback turtles using state space models. Journal of Experimental Marine Biology and Ecology, 356, 128-135. doi: 10.1016/j.jembe.2007.12.020

Barkley, A.N., Fisk, A.T., Hedges, K.J., Treble, M.A. \& Hussey, N.E. (2018). Transient movements of a deep-water flatfish in coastal waters: Implications of inshore-offshore connectivity for fisheries management. Journal of Applied Ecology, online first, doi $10.1111 / 1365-2664.13079$

Bigg, G.R., Jickells, T.D., Liss, P.S., \& Osborn, T.J. (2003). The role of the oceans in climate. International Journal of Climatology, 23, 1127-1159. doi: 10.1002/joc.926

Block, B.A., Dewar, H., Blackwell, S.B., Williams, T.D., Prince, E.D., Farwell, C.J., ... Fudge, D. (2001). Migratory movements, depth preference, and thermal biology of Atlantic Bluefin tuna. Science, 293, 1310-1314. doi: 10.1126/science.1061197 
Campana, S.E., Fisk, A.T., \& Klimley, A.P. (2015). Movements of Arctic and northwest Atlantic Greenland shark (Somniosus microcephalus) monitored with archival pop-up tags suggest long-range migrations. Deep Sea Research Part II, 115, 109-115. doi: 10.1016/j.dsr2.2013.11.001

Comfort, C.M., \& Weng, K.C. (2015). Vertical habitat and behavior of the bluntnose sixgill shark in Hawaii. Deep Sea Research Part II, 115, 116-126. doi: 10.1016/j.dsr2.2014.04.005

Chittenden, C.M., Adlandsvik, B., Pedersen, O.P., Righton, D., \& Rikardsen, A.H. (2013). Testing a model to track fish migrations in polar regions using pop-up satellite archival tags. Fisheries and Oceanography, 22, 1-13. doi: 10.1111/fog. 12000

Christiansen, J.S., Mecklenburg, C.W., \& Karamushko, O.V. (2013). Arctic marine fishes and their fisheries in light of global change. Global Change Biology, 20(2), 352-359. doi: $10.1111 / \mathrm{gcb} .12395$

Cotton, C.F., \& Grubbs, R.D. (2015). Biology of deep-water chondrichthyans: Introduction. Deep Sea Research Part II, 115, 1-10. doi: 10.1016/j.dsr2.2015.02.030

Daly, R.K., Williams, A., Green, A., Barker, B., \& Brodie, P. (2015). Can marine reserves conserve vulnerable sharks in the deep sea? A case study of Centrophorus zeehaani (Centrophoridae), examined with acoustic telemetry. Deep Sea Research Part II, 115, 127-136. doi: 10.1016/j.dsr2.2014.05.017

Danovaro, R., Gambi, C., Dell'Anno, A., Corinaldesi, C., Fraschetti, S., Vanreusel, A., Vincx, M., \& Gooday, A.J. (2008). Exponential decline in deep-sea ecosystem functioning linked to benthic biodiversity loss. Current Biology, 18 (1), 1-8. doi: 10.1016/j.cub.2007.11.056

Domeier, M.L., Nasby-Lucas, N. (2013). Two-year migration of adult female white 
sharks (Carcharodon carcharias) reveals widely separated nursery areas and conservation concerns. Animal Biotelemetry, 1(2), 1-9. doi: 10.1186/2050-3385-1-2

Fisk, A.T., Lyderson, C., \& Kovacs, K.M. (2012). Archival pop off tracking of Greenland sharks Somniosus microcephalus in the high Arctic waters of Svalbard, Norway. Marine Ecology Progress Series, 468, 255-265. doi: 10.3354/meps09962

Godø, O.R., \& Haug, T. (1988). Tagging and recapture of Atlantic halibut (Hippoglossus hippoglossus) in Norwegian waters. ICES Journal of Marine Science, 44, 169-179. doi: 10.1093/icesjms/44.2.169

Grassle, J.F., \& Maciolek, N.J. (1992). Deep-sea species richness: regional and local diversity estimates from quantitative bottom samples. The American Naturalist, 139(2), 313-341.

Hansen, P.M. (1963). Tagging experiments with the Greenland shark (Somniosus microcephalus) in Subarea 1. ICNAF Special Publication, 4, 172-175.

Heide-Jorgensen, M.P., Laidre, K.L., Burt, M.L., Borchers, T.A., Marques, T.A., Hansen, R.G., Rasmussen, M, \& Fossette, S. (2010) Abundance of narwhals (Monodon monoceros) on the hunting grounds in Greenland. Journal of Mammalogy, 91, 11351151.

Heide-Jorgensen, M.P., Burt, L.M., Hansen, R.G., Nielsen, N.H., Rasmussen, M., Fossette, S., \& Stern, H. (2012) The significance of the North Water Polyna to Arctic predators. Ambio, 42, 596-610.

Hunter, E., Aldridge, J.N., Metcalfe, J.D., \& Arnold, G.P. (2003). Geolocation of freeranging fish on the European continental shelf as determined from environmental variables. I. Tidal location method. Marine Biology, 142, 601-609. 
Hunter, E., Metcalfe, J.D., Holford, A.B.H., \& Arnold, G.P. (2004). Geolocation of freeranging fish on the European continental shelf as determined from environmental variables II: Reconstruction of plaice ground tracks. Marine Biology, 144, 787-798.

Hussey, N.E., Kessel, S.T., Aarestrup, K., Cooke, S.J., Cowley, P.D., Fisk, A.T., ... Whoriskey, F.G. (2015a). Aquatic animal telemetry: A panoramic window into the underwater world, Science, 348, 6240. doi: 10.1126/science.1255642

Hussey, N.E., Cosandey-Godin, A., Walter, R.P., Hedges, K.J., VanGerwen-Toyne, M., Barkley, A.N., Kessel, S.T., \& Fisk, A.T. (2015b). Juvenile Greenland sharks Somniosus microcephalus (Bloch and Schneider, 1801) in the Canadian Arctic. Polar Biology, 38, 493-504. doi: 10.1007/s00300-014-1610-y

Hussey, N.E., Hedges, K.J., Barkley, A.N., Treble, M.A., Peklova, I., Webber, D.M., ... Fisk, A.T. (2017). Movements of a deep-water fish: establishing marine fisheries management boundaries in coastal Arctic waters. Ecological Applications, 27, 687-704. doi:10.1002/eap.1485.

Kaiser M.J., Collie, J.S., Hall, S.J., Jennings, S., \& Poiner, I.R. (2002). Modification of marine habitats by trawling activities: prognosis and solutions. Fish and Fisheries, 3(2), 114-136. doi: 10.1046/j.1467-2979.2002.00079

Koslow, J.A. (1996). Energetic and life-history patterns of deep-sea benthic, benthopelagic and seamount-associated fish. Journal of Fish Biology, 49, 54-74. doi: 10.1111/j.1095-8649.1996.tb06067.x

Koslow, J.A., Boehlert, G.W., Gordon, J.D.M., Haedrich, R.L., Lorance, P., \& Parin, N. (2000). Continental slope and deep-sea fisheries: implications for a fragile ecosystem. ICES Journal of Marine Science, 57(3), 548-557. doi: 10.1006/jmsc.2000.0722 
Lea, J.S.E., Wetherbee, B.M., Queiroz, N., Burnie, N., Aming, C., Sousa, L.L., ... Shivji, M.S. (2015). Repeated, long-distance migrations by a philopatric predator targeting highly contrasting ecosystems. Scientific Reports, 5, 11202. doi: 10.1038/srep11202

Lennox, R.J., Aarestrup, K., Cooke, S.J., Cowley, P.D., Deng, Z.D., Fisk, A.T., ... Young, N. (2017) Envisioning the future of aquatic animal tracking: technology, science, and application. BioScience, 67 (10), 884-896. doi: 10.1093/biosci/bix098

MacNeil, M.A., McMeans, B.C., Hussey, N.E., Vecsei, P., Svavarsson, J., Kovacs, K.M., ... Fisk, A.T. (2012). Biology of the Greenland shark Somniosus microcephalus. Journal of Fish Biology, 80, 991-1018. doi: 10.1111/j.1095-8649.2012.03257.x

Melling H., Gratton, Y., \& Ingram, G. (2000). Ocean circulation within the North water polynya of Baffin Bay. Atmosphere-Ocean, 39(3), 301-325. doi: $10.1080 / 07055900.2001 .9649683$

Morato, T., Cheung, W.W.L., \& Pitcher, T.J. (2006). Vulnerability of seamount fish to fishing: fuzzy analyses of life history attributes. Journal of Fish Biology, 68, 209-221. doi: 10.1111/j.0022-1112.2006.00894.x

Musyl, M.K., Brill, R.W., Currran, D.S., Gunn, J.S., Hartog, J.R., Hill, R.D., .. Brainard, R.E. (2001). Ability of archival tags to provide estimates of geographic position based on light intensity. In J.R. Silbert \& J.L. Nielsen (Eds.), Electronic tagging and tracking in Marine Fishes (pp. 343-368) Dordrecht: Kluwer Academic Press.

Neuenfeldt, S., Hinrichsen, H.H., Nielsen, A., \& Andersen, K.H. (2007). Reconstructing migrations of individual cod (Gadus morha L.) in the Baltic Sea by using electronic data storage tags. Fisheries Oceanography 16, 526-535. doi: 10.1111/j.13652419.2007.00458.x 
Nielsen, A., Bigelow, K.A., Musyl, M.K., \& Sibert, J.R. (2006). Improving light-based geolocation by including sea surface temperature. Fisheries Oceanography, 15(4), 314325. doi: 10.1111/j.1365-2419.2005.00401.x

Nielsen, J., Hedeholm, R.B., Heinemeier, J., Bushnell, P.G., Christiansen, J.S., Olsen, J., Ramsey, C.W., Brill, R.W., Simon, M., Steffensen, K.F. \& Steffensen, J.F. (2016) Eye lens radiocarbon reveals centuries of longevity in the Greenland shark (Somniosus microcephalus). Science, 353: 702-704. doi: 10.1126/science.aaf1703

Patterson, T.A., Evans, K., Carter, T.I., \& Gunn, J.S. (2008). Movement and behaviour of large southern Bluefin tuna (Thunnus maccoyii) in the Australian region determined using pop-up satellite archival tags. Fisheries Oceanography, 17(5), 352-367. doi: 10.1111/j.1365-2419.2008.00483.x

Peklova, I., Hussey, N.E., Hedges, K.J., Treble, M.A., \& Fisk, A.T. (2012). Depth and temperature preferences of the deepwater flatfish Greenland halibut Reinhardtius hippoglossoides in an Arctic marine ecosystem. Marine Ecology Progress Series, 467, 193-205. doi: 10.3354/meps09899

Peklova, I., Hussey, N.E., Hedges, K.J., Treble, M.A., \& Fisk, A.T. (2014). Movement, depth and temperature preferences of an important bycatch species, Arctic skate Amblyraja hyperborea, in Cumberland Sound, Canadian Arctic. Endangered Species Research, 23, 229-240. doi: 10.3354/esr00563

Reeves, R.R., \& St. Aubin, D.J. (2001). [Introduction]: Belugas and Narwhales: Application of new technology to whale science in the Arctic. Arctic, 54, pp iii-vi.

Rodriguez-Cabello, C., \& Sanchez, F. (2014). Is Centrophorus squamosus a highly migratory deep-water shark? Deep Sea Research Part I, 92, 1-10. doi: 10.1016/j.dsr.2014.06.005 
Schiermeier, Q. (2012). The great Arctic oil race begins: conservationists fear spills in icy waters as Norway awards oil-production licences. Nature, 482, 13-14.

Skomal, G.B., Zeeman, S.I., Chisholm, J.H., Summers, E.L., Walsh, H.J., McMahon, K.W., \& Thorrold, S.R. (2009). Transequatioral migrations by basking sharks in the western Atlantic Ocean. Current Biology, 19, 1019-1022. doi: 10.1016/j.cub.2009.04.019

Thurber, A.R., Sweetman, A.K., Narayanaswamy, B.E., Jones, D.O.B., Ingels, J., \& Hansman, R.L. (2014). Ecosystem function and services provided by the deep sea. Biogeosciences, 11, 3941-3963. doi: 10.5194/bg-11-3941-2014

Watanabe, Y.Y., Lydersen, C., Fisk, A.T., \& Kovacs, K.M. (2012) The slowest fish: Swim speed and tail beat frequency of Greenland sharks. Journal of Experimental Marine Biology and Ecology, 426-427, 5-11.

Weng, K.C. (2013). A pilot study of deepwater fish movement with respect to marine reserves. Animal Biotelemetry, 1, 17. doi: 10.1186/2050-3385-1-17

Yano, K., Stevens, J.D., \& Compagno, L.J.V. (2007) Distribution, reproduction and feeding of the Greenland shark Somniosus (Somniosus) microcephalus, with notes on two other sleeper sharks, Somniosus (Somniosus) pacificus and Somniosus (Somniosus) antarcticus. Journal of Fish Biology, 70, 374-390. doi: 10.1111/j.10958649.2007.01308.x

Figure 1: Multiple mrPATs and a miniPAT attached to the dorsal fin of a Greenland shark using the designed attachment plate. Inset photographs show top down and lateral view of one attachment plate with scale bar.

Figure 2: Expected release dates for each mrPAT (marked by open squares) plotted with the date of each mrPAT location estimate as a circle graduated by the associated error of 
that ARGOS location (in meters). Note that the delayed reporting of Shark 5's first mrPAT resulted in overlap of transmissions from mrPATs 1 and 2.

Figure 3: All location quality 1, 2 and 3 transmissions from mrPATs and a miniPAT that released from Shark 1. X's denote the chosen pop-up location of the tag, as well as the tagging location of the shark in Steiness Fjord. Arrows indicate the average direction of drift, and the hashed area prior to pop-up location is the estimated location error for the first location, accounting for time from expected release, average drift speed, and direction. Red is mrTag 1, blue mrTag 2, purple mrTag 3, yellow mrTag 4 and green the miniPAT tag.

Figure 4: Minimum and maximum daily temperatures recorded by multiple mrPATs per shark compared with summarized miniPAT data. Note the line break on the y-axis of Shark 2 plot.

Figure 5: Map showing directed migration of Greenland sharks from their tagging location in Steiness Fjord (marked with an ' $X$ ') to northwest Greenland. Each point indicates a pop-up location for mrPATs and miniPATs; each colour represents an individual shark and arrows indicate direction of movement. Possible location errors of the tags due to the difference in time from expected to actual report date and average drift speed are shown on the legend to the right. The triangle marked in the error circle is an indication of the likely direction from which the tag drifted and $\mathrm{n} / \mathrm{a}$ values are given for tags were there was insufficient data to calculate error (too few or no locations given within a 1, 2 or 3 class). (a) Sharks tagged in 2015, (b) Sharks tagged in 2014, (c) Map of Canada and Greenland with the study location highlighted in the red box. 


\section{FIGURES}

Figure 1

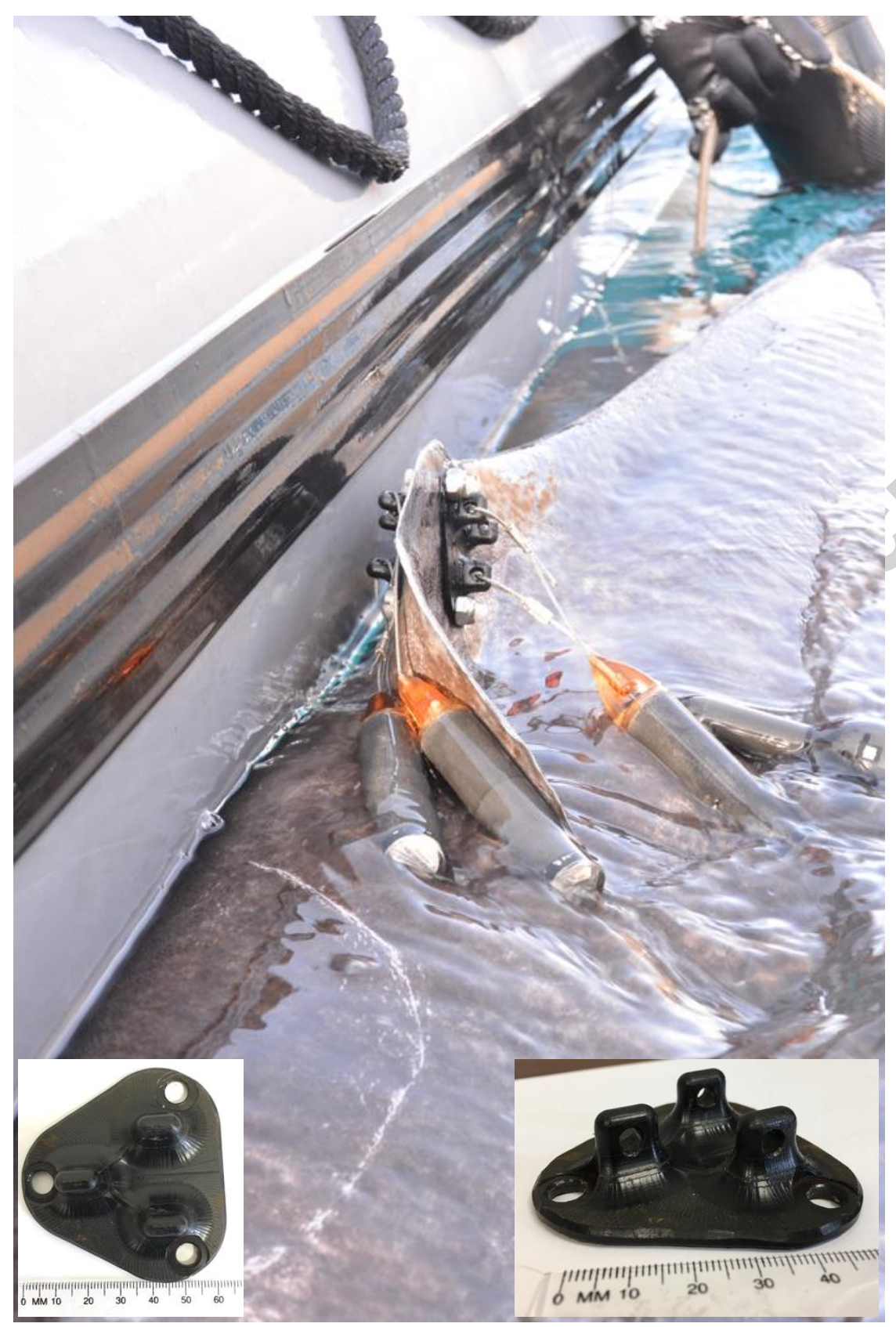


Figure 2

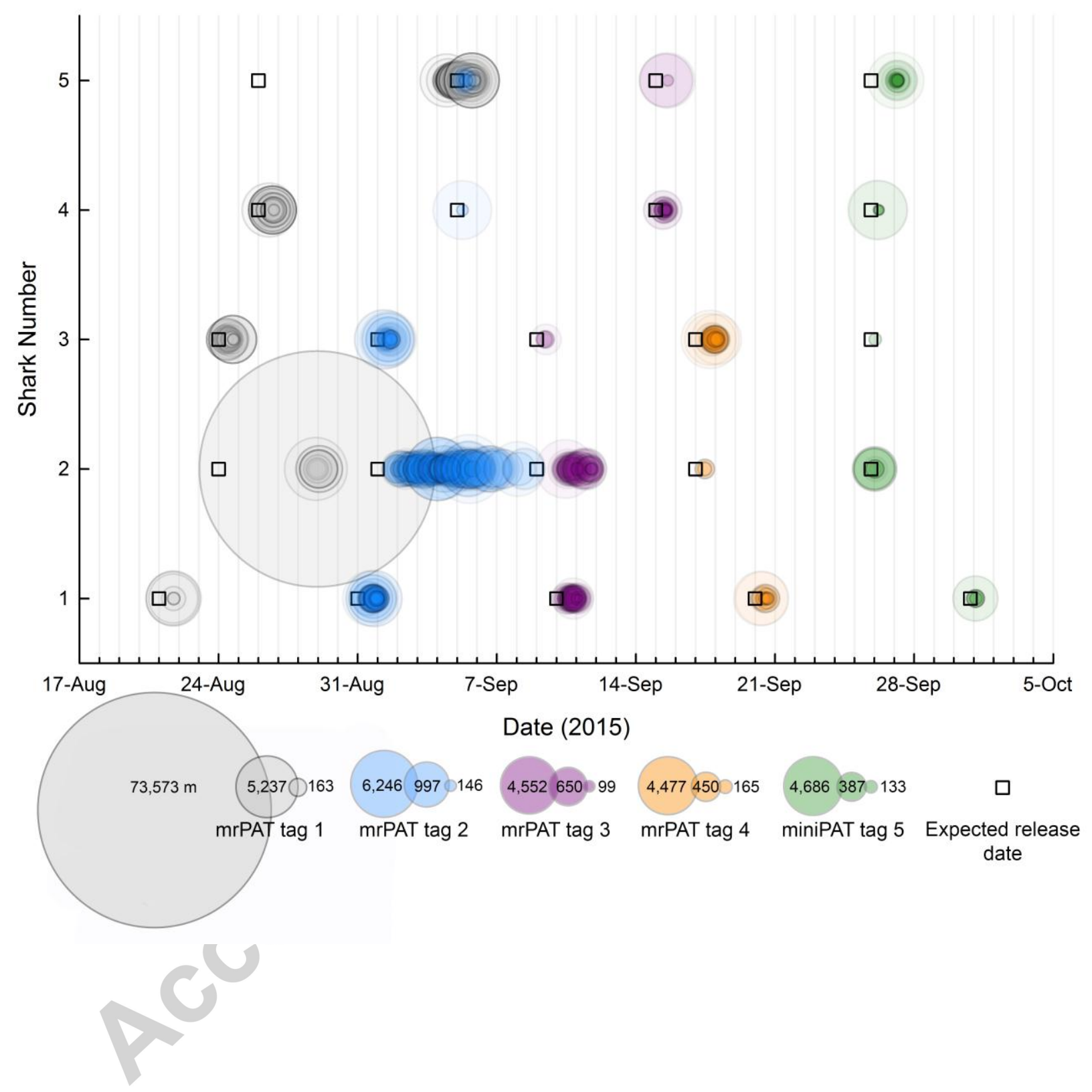


Figure 3

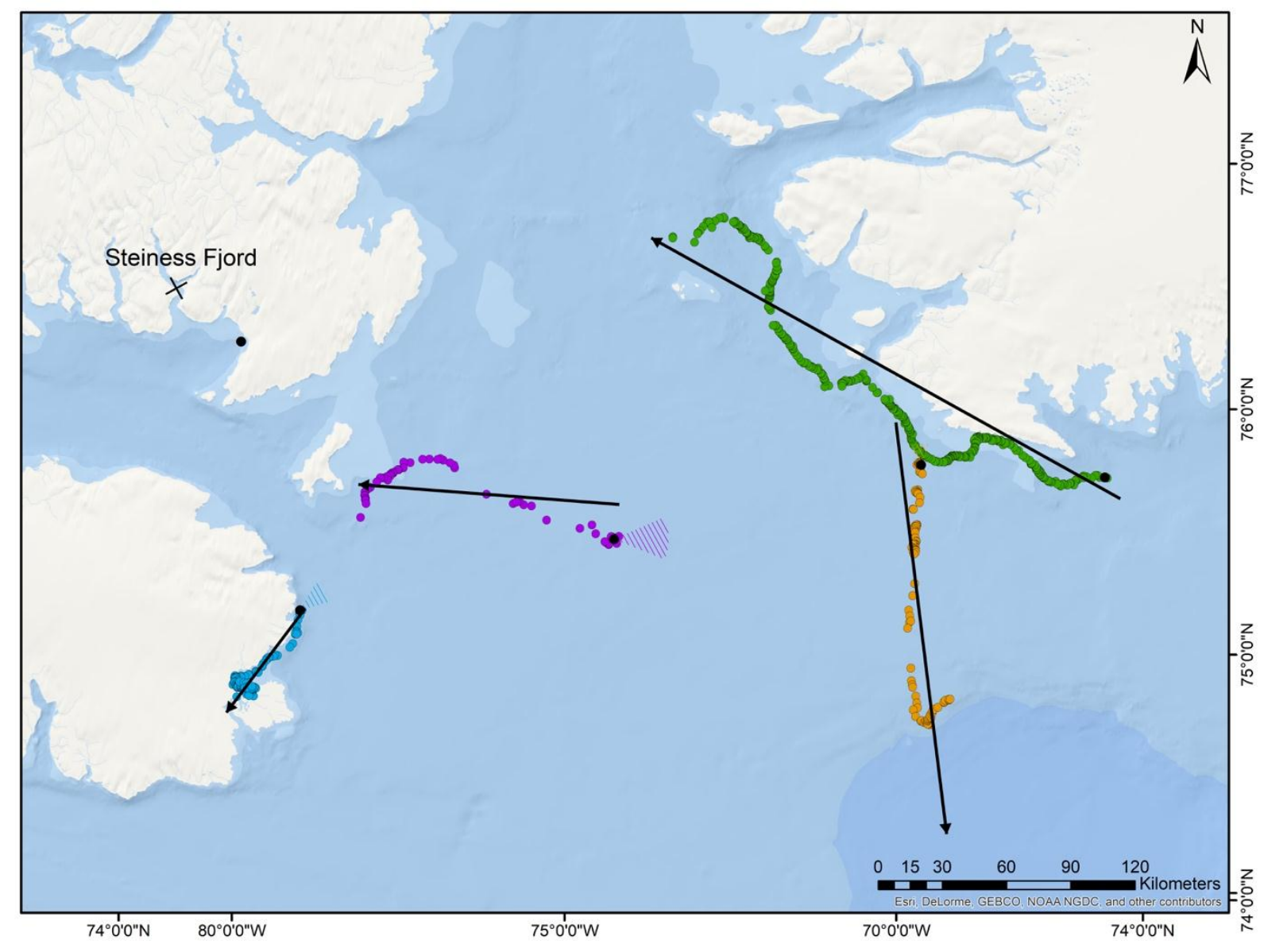




\section{Figure 4}
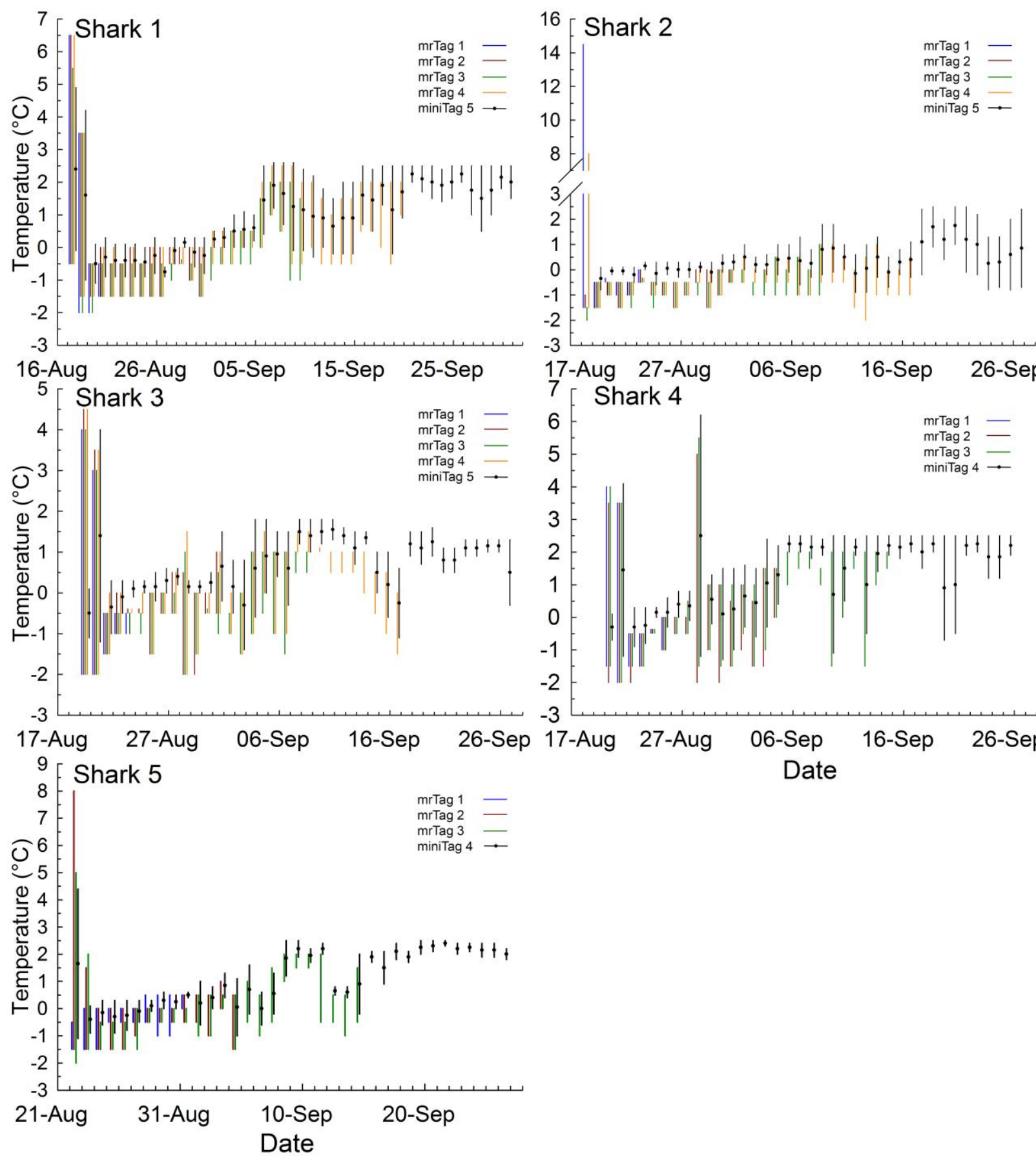


\section{Figure 5}

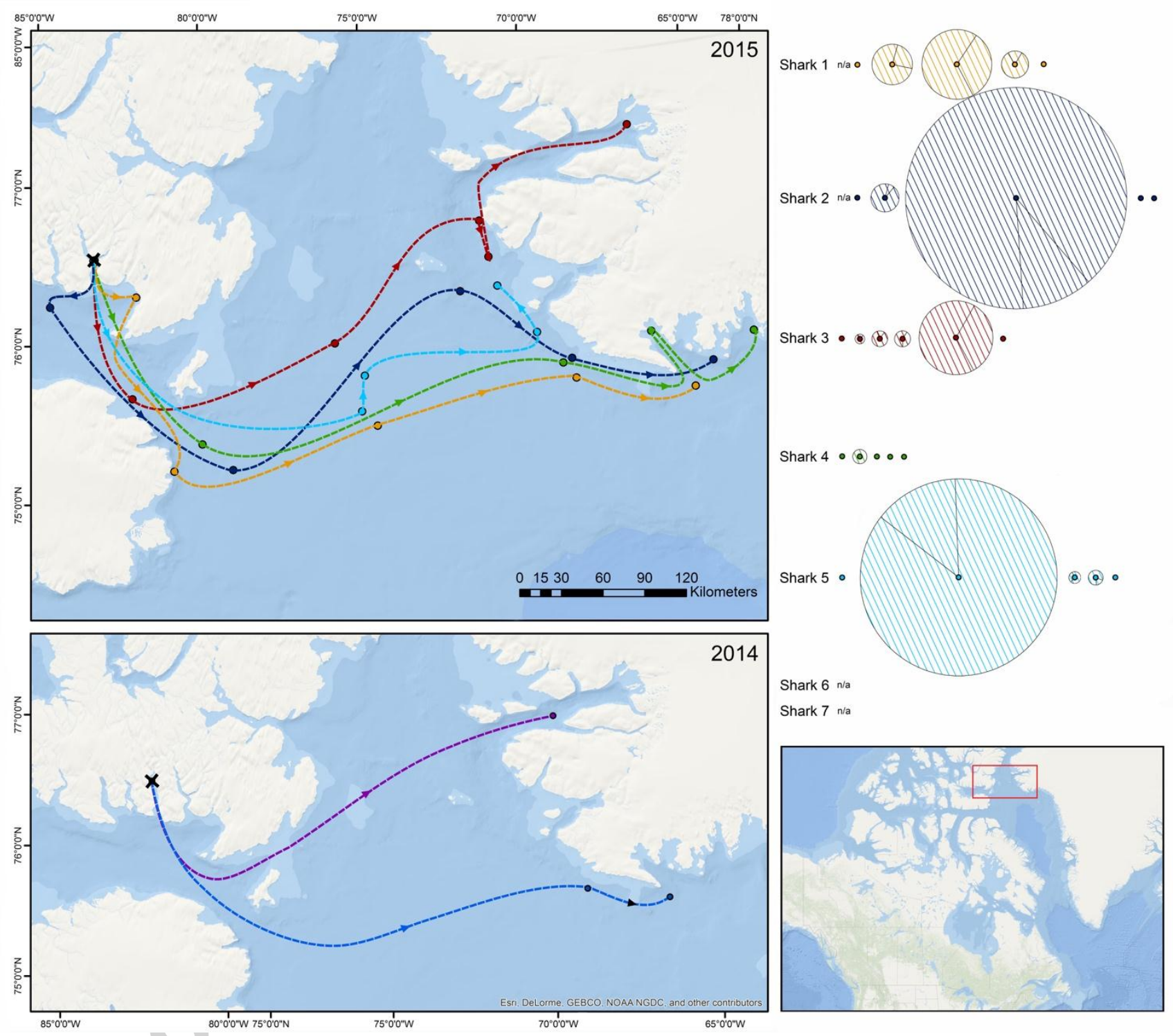

Table 1: Summary mrPAT and miniPAT data for each Greenland shark, including the expected and actual report date of the tag. Actual report date is the day that the very first Argos signal was received, regardless if there was any location data available. Date of chosen location is the date when the tag first transmitted a location quality (LC) of 1, 2 or 3. Time is calculated as the difference from the expected report time to the time of the chosen location for that tag. Average (ave) drift was calculated using only LC's 1, 2 and 3 in $\mathrm{m} / \mathrm{s}$, n/a given when either none or only one LC 1,2 or 3 was reported. 


\begin{tabular}{|c|c|c|c|c|c|c|c|c|c|}
\hline $\begin{array}{c}\text { Shar } \\
\mathrm{k}\end{array}$ & $\begin{array}{l}\text { Releas } \\
\text { e date }\end{array}$ & $\begin{array}{l}\text { Tag } \\
\text { type }\end{array}$ & $\begin{array}{l}\text { Tag } \\
\text { SN }\end{array}$ & $\begin{array}{c}\text { Expecte } \\
\text { d report } \\
\text { date }\end{array}$ & $\begin{array}{c}\text { Actua } \\
1 \\
\text { report } \\
\text { date }\end{array}$ & $\begin{array}{c}\text { Date of } \\
\text { chosen } \\
\text { locatio } \\
n\end{array}$ & $\begin{array}{c}\text { Time } \\
(\mathrm{h})\end{array}$ & $\begin{array}{c}\text { Ave } \\
\text { Drif } \\
t\end{array}$ & $\begin{array}{c}\text { Compass } \\
\text { Directio } \\
n\end{array}$ \\
\hline \multirow[t]{5}{*}{1} & $\begin{array}{l}17-08- \\
2015\end{array}$ & mrPAT & $\begin{array}{c}15235 \\
4\end{array}$ & $\begin{array}{c}21-08- \\
2015\end{array}$ & $\begin{array}{c}21- \\
08- \\
2015\end{array}$ & $\begin{array}{c}21-08- \\
2015\end{array}$ & 17.52 & $n / a$ & $\mathrm{n} / \mathrm{a}$ \\
\hline & & $m r P A T$ & $\begin{array}{c}15234 \\
4\end{array}$ & $\begin{array}{c}31-08- \\
2015\end{array}$ & $\begin{array}{c}31- \\
08- \\
2015\end{array}$ & $\begin{array}{c}31-08- \\
2015\end{array}$ & 16.59 & 2.18 & 247.03 \\
\hline & & $m r P A T$ & $\begin{array}{c}15234 \\
8\end{array}$ & $\begin{array}{c}10-09- \\
2015\end{array}$ & $\begin{array}{c}10- \\
09- \\
2015\end{array}$ & $\begin{array}{c}11-09- \\
2015\end{array}$ & 26.78 & 1.26 & 270.48 \\
\hline & & mrPAT & $\begin{array}{c}15234 \\
5\end{array}$ & $\begin{array}{c}20-09- \\
2015\end{array}$ & $\begin{array}{c}20- \\
09- \\
2015\end{array}$ & $\begin{array}{c}20-09- \\
2015\end{array}$ & 14.91 & 1.36 & 171.01 \\
\hline & & $\begin{array}{l}\text { miniPA } \\
T\end{array}$ & $\begin{array}{c}14136 \\
7\end{array}$ & $\begin{array}{c}30-09- \\
2015\end{array}$ & $\begin{array}{c}01- \\
10- \\
2015 \\
\end{array}$ & $\begin{array}{c}01-10- \\
2015\end{array}$ & 6.53 & 2.35 & 278.86 \\
\hline \multirow[t]{5}{*}{2} & $\begin{array}{l}18-08- \\
2015\end{array}$ & $m r P A T$ & $\begin{array}{c}15235 \\
6\end{array}$ & $\begin{array}{c}24-08- \\
2015\end{array}$ & $\begin{array}{c}24- \\
08- \\
2015\end{array}$ & $\begin{array}{c}28-08- \\
2015\end{array}$ & $\begin{array}{c}119.4 \\
9\end{array}$ & $n / a$ & $\mathrm{n} / \mathrm{a}$ \\
\hline & & $m r P A T$ & $\begin{array}{c}15234 \\
9\end{array}$ & $\begin{array}{c}01-09- \\
2015\end{array}$ & $\begin{array}{c}01- \\
09- \\
2015\end{array}$ & $\begin{array}{c}01-09- \\
2015\end{array}$ & 23.21 & 0.74 & 212.08 \\
\hline & & mrPAT & $\begin{array}{c}15233 \\
9\end{array}$ & $\begin{array}{c}09-09- \\
2015\end{array}$ & $\begin{array}{c}09- \\
09- \\
2015\end{array}$ & $\begin{array}{c}11-09- \\
2015\end{array}$ & 66.02 & 1.76 & 287.77 \\
\hline & & $m r P A T$ & $\begin{array}{c}15235 \\
5\end{array}$ & $\begin{array}{c}17-09- \\
2015\end{array}$ & $\begin{array}{c}17- \\
09- \\
2015\end{array}$ & $\begin{array}{c}17-09- \\
2015\end{array}$ & 11.30 & 1.15 & 249.69 \\
\hline & & $\begin{array}{l}\text { miniPA } \\
T\end{array}$ & $\begin{array}{c}14136 \\
5\end{array}$ & $\begin{array}{c}25-09- \\
2015\end{array}$ & $\begin{array}{c}25- \\
09- \\
2015\end{array}$ & $\begin{array}{c}26-09- \\
2015\end{array}$ & 4.92 & 2.25 & 278.80 \\
\hline \multirow[t]{5}{*}{3} & $\begin{array}{l}19-08- \\
2015\end{array}$ & $m r P A T$ & $\begin{array}{c}15235 \\
0\end{array}$ & $\begin{array}{c}24-08- \\
2015\end{array}$ & $\begin{array}{c}24- \\
08- \\
2015\end{array}$ & $\begin{array}{c}24-08- \\
2015\end{array}$ & 8.63 & 2.58 & 178.69 \\
\hline & & mrPAT & $\begin{array}{c}15235 \\
2\end{array}$ & $\begin{array}{c}01-09- \\
2015\end{array}$ & $\begin{array}{c}01- \\
09- \\
2015\end{array}$ & $\begin{array}{c}01-09- \\
2015\end{array}$ & 12.08 & 1.46 & 183.56 \\
\hline & & $m r P A T$ & $\begin{array}{c}15234 \\
0\end{array}$ & $\begin{array}{c}09-09- \\
2015\end{array}$ & $\begin{array}{c}09- \\
09- \\
2015\end{array}$ & $\begin{array}{c}09-09- \\
2015\end{array}$ & 11.25 & 1.72 & 293.59 \\
\hline & & mrPAT & $\begin{array}{c}15234 \\
1\end{array}$ & $\begin{array}{c}17-09- \\
2015\end{array}$ & $\begin{array}{c}17- \\
09- \\
2015\end{array}$ & $\begin{array}{c}17-09- \\
2015\end{array}$ & 21.20 & 2.08 & 288.15 \\
\hline & & miniPA & 14136 & 25-09- & $26-$ & 26-09- & 4.93 & 1.85 & 273.72 \\
\hline
\end{tabular}




\begin{tabular}{|c|c|c|c|c|c|c|c|c|c|}
\hline & & $T$ & 9 & 2015 & $\begin{array}{c}09- \\
2015 \\
\end{array}$ & 2015 & & & \\
\hline \multirow[t]{4}{*}{4} & $\begin{array}{l}20-08- \\
2015\end{array}$ & mrPAT & $\begin{array}{c}15235 \\
1\end{array}$ & $\begin{array}{c}26-08- \\
2015\end{array}$ & $\begin{array}{c}26- \\
08- \\
2015\end{array}$ & $\begin{array}{c}26-08- \\
2015\end{array}$ & 37.16 & 1.35 & 159.36 \\
\hline & & $m r P A T$ & $\begin{array}{c}15235 \\
3\end{array}$ & $\begin{array}{c}05-09- \\
2015\end{array}$ & $\begin{array}{c}05- \\
09- \\
2015\end{array}$ & $\begin{array}{c}05-09- \\
2015\end{array}$ & 6.28 & 1.95 & 269.73 \\
\hline & & $m r P A T$ & $\begin{array}{c}15234 \\
7\end{array}$ & $\begin{array}{c}15-09- \\
2015\end{array}$ & $\begin{array}{c}15- \\
09- \\
2015\end{array}$ & $\begin{array}{c}15-09- \\
2015\end{array}$ & 8.80 & 0.85 & 283.06 \\
\hline & & $\begin{array}{l}\operatorname{miniPA} \\
T\end{array}$ & $\begin{array}{c}15207 \\
0\end{array}$ & $\begin{array}{c}25-09- \\
2015\end{array}$ & $\begin{array}{c}26- \\
09- \\
2015\end{array}$ & $\begin{array}{c}26-09- \\
2015\end{array}$ & 8.75 & 2.68 & 277.02 \\
\hline \multirow[t]{4}{*}{5} & $\begin{array}{l}22-08- \\
2015\end{array}$ & mrPAT & $\begin{array}{c}15234 \\
6\end{array}$ & $\begin{array}{c}26-08- \\
2015\end{array}$ & $\begin{array}{c}01- \\
09- \\
2015\end{array}$ & $\begin{array}{c}04-09- \\
2015\end{array}$ & $\begin{array}{c}227.5 \\
6\end{array}$ & 1.01 & 133.05 \\
\hline & & $m r P A T$ & $\begin{array}{c}15234 \\
2\end{array}$ & $\begin{array}{c}05-09- \\
2015\end{array}$ & $\begin{array}{c}05- \\
09- \\
2015\end{array}$ & $\begin{array}{c}09-05- \\
2015\end{array}$ & 10.65 & 1.71 & 94.17 \\
\hline & & $m r P A T$ & $\begin{array}{c}15234 \\
3\end{array}$ & $\begin{array}{c}15-09- \\
2015\end{array}$ & $\begin{array}{c}15- \\
09- \\
2015\end{array}$ & $\begin{array}{c}15-09- \\
2015\end{array}$ & 14.49 & 1.43 & 295.66 \\
\hline & & $\begin{array}{l}\operatorname{miniPA} \\
T\end{array}$ & $\begin{array}{c}15206 \\
9\end{array}$ & $\begin{array}{r}25-09 \\
2015\end{array}$ & $\begin{array}{c}27- \\
09- \\
2015\end{array}$ & $\begin{array}{c}27-09- \\
2015\end{array}$ & 30.26 & 2.02 & 280.57 \\
\hline
\end{tabular}

Table 2: Biological information on the five tagged Greenland sharks. Days at liberty calculated from the release date to the date of the chosen location for the last tag to release from that animal. Total distance travelled is calculated by adding the direct-line distance between the release locations for each tag sequentially.

\begin{tabular}{lcccccc} 
Shark & $\begin{array}{c}\text { Total length } \\
(\mathrm{cm})\end{array}$ & $\begin{array}{c}\text { Fork length } \\
(\mathrm{cm})\end{array}$ & Sex & Maturity & $\begin{array}{c}\text { Days at } \\
\text { liberty }\end{array}$ & $\begin{array}{c}\text { Total distance } \\
\text { travelled }(\mathrm{km})\end{array}$ \\
\hline $\mathbf{1}$ & 239 & n/a & Male & Sub adult & 45 & 543.70 \\
$\mathbf{2}$ & 175 & 165.5 & Female & Juvenile & 38 & 617.12 \\
$\mathbf{3}$ & 300 & 290 & Male & Sub adult & 37 & 547.86 \\
$\mathbf{4}$ & 310 & 302 & Male & Mature & 36 & 553.95 \\
$\mathbf{5}$ & 278 & 269 & Female & Sub adult & 34 & 414.27 \\
\hline $\mathbf{2 0 1 5}$ & & & & 42 & 464.75
\end{tabular}




\section{Highlights:}

- Currently complex to track horizontal movements of deep water species

- Prototype mrPATs, the smallest available satellite tag, were tested to address this question

- The first near real time horizontal tracks for Greenland sharks were derived through attachment and sequential release of multiple mrPATs per shark

- The adopted experimental design revealed a timed migration of sharks from Steiness Fjord, Canada to northwest Greenland

- mrPATs have applications for understanding the movements of large and medium size fish, marine mammals and to validate retrospective movement models using archival depth/temperature data 